\title{
Leverage as a Moderator of the Effect of Company Size, Managerial Ownership, and Conflict of Interest on Accounting Conservatism
}

\author{
Siti Nurmala Sari ${ }^{* 1}$ and Linda Agustina ${ }^{2}$ \\ 1,2 Accounting Department, Faculty of Economics, Universitas Negeri Semarang, Indonesia
}

\section{ARTICLE INFO}

\section{Article History:}

Received January $28^{\text {th }}, 2021$

Accepted March $8^{\text {th }}, 2021$

Available March $15^{\text {th }}, 2021$

\section{Keywords: \\ Accounting Conservatism; Company Size; Conflict of Interest; Leverage; Managerial Ownership}

\begin{abstract}
This study aims to examine the influence of company size, managerial ownership, and conflict of interest to accounting conservatism with leverage as the moderating variable. The population was mining companies and infrastructure, utilities, and transportation companies which were listed on the Indonesia Stock Exchange (IDX) from 2015 to 2018, which are 118 companies. The sample was determined by purposive sampling which resulted in 12 companies with 36 units of analysis. The data were collected by using documentaries. The analysis techniques used descriptive and inferential with the help of IBM SPSS version 21. The results showed that managerial ownership had a negative influence and conflicts of interest had a positive influence to accounting conservatism, company size had not influenced to accounting conservatism, and leverage moderated the relationship of managerial ownership to accounting conservatism, but it was unable to moderate the relationship of company size and conflict of interest to accounting conservatism. The conclusion of this study is the low managerial ownership presses the existence of expropriation; therefore, it can increase the accounting conservatism. The high conflict of interest increases the application of accounting conservatism to reduce conflicts that occur. Meanwhile, leverage influences the company's financial risk, therefore it is able to moderate the influence of managerial ownership to accounting conservatism.
\end{abstract}

(C) 2021 Published by UNNES. This is an open access article under the CC BY license (http://creativecommons.org/licenses/by/4.0/)

\section{INTRODUCTION}

Financial statement is a report that reflects corporate performance in a certain period. Harrison Jr. et al. (2012) stated financial statements as business documents intended for various user groups, including managers, investors, creditors, and regulatory agents to report the results of company activities. In accordance with International Financial Reporting Standards (IFRS) Framework, financial statements aim to provide information regarding the financial position, performance, and changes in the financial position of an entity that are useful to users when making economic decisions. Therefore, the qualified financial statement which is in accordance with the applicable standards is highly needed so that it can be accounted for.

Accounting conservatism is one of the accounting principles that produces relevant and reliable figures which is used as an effort to present qualified financial statements. Conservatism described by Suwardjono

\footnotetext{
*E-mail: sitinurmalasari1997@gmail.com

_Address: L2 Building 2nd floor, Campus Sekaran, Gunungpati, Semarang, Indonesia, 50229
}

(2017) is an attitude in facing uncertainty to take action or decision. Conservatism also implies prudence by sacrificing something to reduce or eliminate the risk that might occur. This principle results in lower profit and asset figures and higher costs and debt figures (Juanda, 2007).

Accounting conservatism can be concluded as a prudential principle in responding to uncertainties and risks that are possible to occur in the future. The implications of this concept for financial reporting according to Suwardjono (2017) is not anticipating the profit or income that is possible to occur but will immediately recognize the cost or loss that is possible to occur. Conservatism acts as a balancer when there is managerial bias, which is strived by balancing manager opportunistic actions with the obligation to conduct verification first. Thus, the financial reporting presented will not be excessive or not modest.

Historically, the concept of accounting conservatism has been used as a guide for many accounting practices. This concept will provide a rational guideline if applied properly. However, this concept is still considered controversial. On the one hand, it is useful to 
avoid manager opportunistic behaviour, on the other hand, conservative accounting will affect the quality of financial statements because the reported information is considered to be biased (Hery, 2017). Watts (2003) argued that conservatism would still be used because conservative financial reporting is still considered beneficial for users and can limit the opportunistic behaviour of managers.

In general, the application of accounting conservatism in Indonesia is still low. The application of accounting conservatism in mining companies from 2014-2016 was $65.4 \%$ in the low interval class with the lowest value of-1,754,859,836,800 (Nabela, 2018). On the manufacturing companies from 2013-2016, it showed $81.39 \%$ which was in the low interval class with the lowest value of -0.2714 and a mean of 0.0093 (Pratiwi, 2017). Furthermore, the financial scandals that are still rife in Indonesia, indirectly illustrate the weak application of accounting conservatism principles. For example, the scandals involving the mining companies in 20032008 such as PT Kaltim Prima Coal, PT Arutmin Indonesia, and their second parent company, PT Bumi Resources Tbk. Apart from the mining companies, PT Kimia Farma (2001) and PT Kereta Api Indonesia (2005) were involved in the case of marking up financial statements.

The selection of the mining companies as well as the infrastructure, utilities, and transportation companies become the object of this study because these two sectors are the main sectors that support the government program 2015-2019 which is still running. The phenomenon of the low accounting conservatism application indicates the need for accounting conservatism to be investigated deeper. The low application of accounting conservatism can also lead to many scandals of financial statement manipulation as described above. The existence of financial statement manipulation cases indicates that the financial statements are not presented according to operational objectives. Thus, financial information needs to be presented in a quality and not misleading manner so that it can be useful for the users.

Previous studies on accounting conservatism which have been done previously raise various factors which still have inconsistent results. Sulastri et al. (2018) and Moeinaddin et al. (2012) in their research indicate a positive influence on the relationship between company size and accounting conservatism. In contrast to Geimechi \& Khodabakhshi (2015) who found the absence of the effect of the relationship between company size and accounting conservatism. Lafond \& Roychowdhury (2008), Mohammed et al. (2017), and Rahmadhani (2015) found the negative effect of managerial ownership with accounting conservatism. Meanwhile, Sinambela \& Almilia (2018) did not find the effect of managerial ownership on accounting conservatism.

The existence of a positive influence of conflict of interest with accounting conservatism is conveyed by Ahmed et al. (2002) and Juanda (2007). In contrast to the research result of Wisuandari \& Putra (2018) which does not find the effect of conflict of interest on accounting conservatism. Sulastri et al. (2018) and Khosrosha- hi et al. (2012) found the positive effect of leverage on accounting conservatism.

This study uses three factors, namely company size, managerial ownership, and conflict of interest as independent variables because these three factors still have many inconsistencies from the results of the previous studies. This inconsistency encourages the researchers to present leverage as a moderating variable. Leverage is chosen because this factor is inherent in companies that always need funds to finance their operations. Especially in the mining, infrastructure, utilities, and transportation sectors which are very risky and have high uncertainty because they require very high and long-term investment costs, which become problems related to funding. Thus, leverage is expected to moderate the relationship of the variables to be examined.

Empirically, the objective of this research is to examine the effect of company size, managerial ownership, and conflict of interest on accounting conservatism with leverage as a moderator. This research refers to and develops research conducted by Sumiari \& Wirama (2016) which examines accounting conservatism as the dependent variable and company size as the independent variable, moderated by leverage as the moderating variable. Managerial ownership and conflict of interest are added as independent variables for the originality of this study. This is because the high managerial ownership will drive expropriation by management, which can weaken the application of accounting conservatism in the companies so that the companies need to suppress managerial ownership so that it is not too high. Meanwhile, conflicts of interest are a factor that often appears in the running of the business wheel so it needs to be handled wisely so that it remains well controlled, and the existence of accounting conservatism can reduce the occurrence of conflicts of interest in the company.

Positive accounting theory as revealed by Chariri \& Ghozali (2007) is a theory that tries to explain accounting phenomena by focusing on observing the reason for an event, or predicting accounting practices under certain conditions. Three hypotheses are tried to be examined in positive accounting theory as revealed by Watts \& Zimmerman (1990) who explained management decision to act conservatively or not. The three hypotheses are Bonus Plan Hypothesis, Debt Equity Hypothesis, and Political Cost Hypothesis. Jensen \& Meckling (1976) stated agency theory as a contract between principal and agent in which both of them want maximum welfare. Jensen and Meckling also revealed that in agency theory, the owner and creditor agency conflicts, as well as management and owner contracts are explained.

Company size is a small or big comparison of companies which can be measured by total assets, total sales, stock market value, and others. Company size can be categorized into large companies, medium companies, and small companies. Watts \& Zimmerman (1990) revealed that larger companies will be more sensitive to political costs as predicted by the political cost hypothesis. It is possible that larger companies will face large political costs. This is due to the government as 
a policymaker makes large companies a priority in tax collection because of the high earnings generated. In order to reduce these political costs, conservative financial reporting will be presented. This is in line with Sulastri et al. (2018), Khosroshahi et al. (2012), Moeinaddin et al. (2012), and Hamdan (2011) who found the positive influence of the relationship between company size and accounting conservatism.

\section{$\mathrm{H}_{1}$ : Company size has a positive effect on accounting conservatism}

The proportion of shares held by people who come from within the company is called managerial ownership. This proportion will affect the actions of managers in financial reporting. The high level of managerial ownership enables managers to expropriate or use control to maximize their own welfare because management is not only pursuing bonuses but also high dividends so that the application of accounting conservatism is getting lower. Meanwhile, low ownership enables managers to be more conservative since managers want to maintain the trust of investors and think about the survival of the company for greater profits in the future.

Managers act on a motive to pursue bonuses. This is in accordance with the bonus plan hypothesis which states that managers will act in line with the bonuses that will be earned (Watts \& Zimmerman, 1990). In order for the target to be met, the manager will maximize profits based on this motive, which causes less conservative earnings reporting and can mislead the users of financial statements. This, it can be concluded that managerial ownership has a negative effect on accounting conservatism. This is in line with Rahmadhani (2015), Mohammed et al. (2017), Xia \& Zhu (2009), and Lafond \& Roychowdhury (2008).

\section{$\mathrm{H}_{2}$ : Managerial ownership has a negative effect on ac- counting conservatism}

A conflict of interest is a description of a conflict that arises because of company policies related to dividends to be paid, which occurs between investors and creditors. Juanda (2007) explained that there is a conflict of interest between investors and creditors as revealed in agency theory. Conflicts of interest occur because of the transfer of assets, acquisition of assets, replacement of assets, or excessive dividend payments used by investors to take advantage of the creditors' funds. Meanwhile, the creditor's interest is hoping for the security of his funds which is alleged to generate profits in the future. Therefore, a conservative and trustworthy financial report is needed in order to avoid the excessive transfer of wealth by investors.

Agency theory explains the contractual relationship between individuals which emphasizes efficient contract arrangements for each party so as to minimize agency conflicts. Conflict of interest between bondholders and shareholders over existing debt is a conflict that may arise. This is because decisions that benefit shareholders may not necessarily be decisions that benefit bondholders. This is in line with Noodezh et al. 2015, Paramita \& Cahyati (2013), and Ahmed et al. (2002) where the conflict of interest has a positive influence on accounting conservatism.

\section{$\mathrm{H}_{3}$ : Conflict of interest has a positive effect on ac- counting conservatism}

The use of accounting methods that reduce profits is more possible to be used by larger companies because related to political costs such as tax payments, the government is more concerned with larger companies. This makes conservative accounting methods an option to reduce high political costs for large companies as revealed in the political cost hypothesis. The presence of leverage will moderate by strengthening the relationship of accounting conservatism which is influenced by company size.

The financial risk faced by the companies will increase due to the increased debt uncollectible ratio. Thus, it can threaten the survival of the company and the safety of creditor funds. This condition encourages creditors to monitor the company more closely and ask for reliable financial statements. Therefore, management will be more careful and not manipulate profits to reduce perceived risk for creditors. Conversely, when the leverage is low, it can reduce the application of accounting conservatism. This is in line with Sumiari \& Wirama (2016).

\section{$\mathrm{H}_{4}$ : Leverage moderates the effect of company size on accounting conservatism}

The proportion of shares owned by parties originating from within the company is usually called managerial ownership. Management will act based on the welfare that will be obtained by maximizing profits to get bonuses and higher welfare as has been revealed in the bonus plan hypothesis. The existence of expropriation is driven by high managerial ownership which impact can reduce conservative accounting applications. The negative effect of the relationship between managerial ownership and accounting conservatism will be moderated by the presence of leverage. The companies will be more conservative and be careful when their debt is high because this is a threat to the company's survival. Conversely, low leverage means that the financial constraints faced by the companies will be smaller so that the aggressive (liberal) accounting method is increasingly used by the companies.

\section{$\mathrm{H}_{5}$ : Leverage moderates the effect of managerial own- ership on accounting conservatism}

Excess dividend payments that are used by investors to take funds from creditors result in a conflict of interest between the two. The existence of a conflict of interest that occurs can be reduced by the application of accounting conservatism. The presence of leverage can moderate the relationship of conflict of interest on accounting conservatism. This is because high leverage can increase the financial risk in the company as explained in the debt-equity hypothesis.

The higher the debt uncollectible ratio, the higher the financial risk to be faced so that it threatens the survival of the company and the security of creditors' funds. This condition drives creditors to monitor the company 
more closely and ask for reliable financial statements. Therefore, management tends to apply more conservative accounting and more careful by presenting a relatively stable (not manipulation) earnings report in order to reduce perceived risk for creditors. Conversely, if the level of debt lower, it can weaken the relationship between managerial ownership and accounting conservatism. This is due to creditors do not closely monitor the company so that management may be less conservative.

\section{$\mathrm{H}_{6}$ : Leverage moderates the effect of conflict of inter- est on accounting conservatism}

\section{RESEARCH METHODS}

The hypothesis testing study which was more causality with a quantitative approach was the research design used in this research. Meanwhile, the secondary data used were audited financial statements. The study population was 118 companies from the mining company sector as well as the infrastructure, utility, and transportation companies listed on the IDX in 20152018. The research sample was determined by purposive sampling, there were 12 companies and 36 units of analysis. The following sampling procedure is shown in table 1 .

One dependent variable, one moderating variable, and three independent variables were used in this research. The following is the operational definition in table 2.

Table 1 Sampling Procedures

\begin{tabular}{llc}
\hline No. Criteria & $\begin{array}{c}\text { Beyond } \\
\text { Criteria }\end{array}$ & Total \\
\hline $1 \quad \begin{array}{l}\text { The mining companies as well } \\
\text { as the infrastructure, utility, }\end{array}$ & 118 \\
and transportation companies & & \\
listed on the IDX during the & & \\
2015-2018 period & & \\
2 & The mining companies and \\
the infrastructure, utility, and & $(26)$ & \\
transportation companies con- & & \\
sistently listed on the IDX dur- & & \\
ing the 2015-2017 period & \\
The mining companies and & $(5)$ & 87 \\
the infrastructure, utility, and & & \\
transportation companies that \\
published financial statements \\
for the period 2015-2017 \\
The mining companies and \\
the infrastructure, utility, and \\
transportation companies hav- \\
ing complete data based on \\
the variables studied.
\end{tabular}

Source: Data processed, 2019
The data in the form of audited financial statements were collected using documentary techniques by downloading from the official IDX website and the issuer's performance site. The data analysis used descriptive analysis and inferential analysis techniques, namely parametric statistics with Moderated Regression Analysis with absolute difference value test. The classical assumption tests used were the normality, multicollinearity, autocorrelation, and heteroscedasticity test, as a prerequisite before doing the hypothesis test. The following shows the regression equation as shown in equation 1 .

$$
\begin{aligned}
Y= & \alpha+\beta_{1} X_{1}+\beta_{2} X_{2}+\beta_{3} X_{3}+\beta_{4}\left|X_{1}-Z\right|+\beta_{5}\left|X_{2}-Z\right| \\
& +\beta_{6}\left|X_{3}-Z\right|+e \ldots \ldots \ldots \ldots \ldots \ldots \ldots \ldots \ldots \ldots \ldots \ldots \ldots \ldots \ldots \ldots \ldots \ldots \ldots \ldots \ldots \ldots \ldots \ldots \ldots
\end{aligned}
$$

\section{RESULTS AND DISCUSSIONS}

The descriptive statistical analysis describes the minimum, maximum, mean, and standard deviation values. Consecutively, accounting conservatism is -0.09833 , $0.06562,-0.0077972$, and 0.04297659 . The company size has values of $26,73817,32.92173,30.1287189$, and 1.77441840. Managerial ownership has values of valued 0.00002, 41.81000, 5.7847372, and 11.85910189. Conflicts of interest have values of $0.44854,28.55274$, 4.2663900, and 5.55632629. Meanwhile, leverage has values of $0.08105,3.31346,1.0127192$, and 0.76159590 .

The Kolmogorov-Smirnov nonparametric statistical test gives Asymp Sig of 0.814>0.05, meaning that the data are normally distributed. The multicollinearity test concludes that there is no correlation between variables and there is no multicollinearity between variables in the regression model because the tolerance value is $>0.10$ and the variance inflation factor (VIF) value shows a value $<10$. The run test results in the absence of autocorrelation as seen from Asymp. Sig of 0.398> 0.05 . The heteroscedasticity test uses the Glejser test with a significance value $>0.05$, which means that there is no heteroscedasticity in the regression model.

Results of hypothesis testing using the absolute difference test as outlined in table 3 . It is obtained Adjusted $\mathrm{R}^{2}$ of 0.296 from the coefficient of determination test. This result means that there is a $29.6 \%$ variation of the dependent variable which can be described by the independent variable and the moderating variable used in this study. Meanwhile, the remaining $70.4 \%$ is explained by other variables outside the model. Furthermore, to test the hypothesis uses equation 2 .

$$
\begin{aligned}
& Y=-0.007+0.006 X_{1}-0.030 X_{2}+0.32 X_{3} \\
& -0.008\left|X_{1}-Z\right|+0.031\left|X_{2}-Z\right| \\
& -0.20\left|X_{3}-Z\right| \ldots \ldots \ldots \ldots \ldots \ldots \ldots \ldots \ldots \ldots \ldots \ldots \ldots . .2
\end{aligned}
$$

\section{The Effect of Company Size on Accounting Conser-} vatism

There is no correlation between company size and accounting conservatism. This result is not in line with the Political Cost Hypothesis which predicts the use of accounting methods that reduce earnings tends to be applied by larger companies. The result shows in the 
Table 2 Operational Definition of the Variables

\begin{tabular}{|c|c|c|}
\hline Variables & Definitions & Measurements \\
\hline $\begin{array}{l}\text { Accounting Con- } \\
\text { servatism (Y) }\end{array}$ & $\begin{array}{l}\text { A concept by accelerating the recognition of } \\
\text { losses and debts, while recognizing assets and } \\
\text { profits is not done in a hurry (Watts, 2003). }\end{array}$ & $\begin{array}{l}Y=(\text { profit after tax }+ \text { depreciation expense }- \\
\text { cash flow)/total asset } \times-1 \\
(\text { Givoly \& Hayn, 2000) }\end{array}$ \\
\hline $\begin{array}{l}\text { Company size } \\
\left(\mathrm{X}_{1}\right)\end{array}$ & $\begin{array}{l}\text { The big or small comparison of assets of a } \\
\text { company (Sulastri et al., 2018). }\end{array}$ & $\begin{array}{l}\mathrm{X}_{1}=\text { Log-Normal Total Annual Assets } \\
\text { (Sulastri et al., 2018) }\end{array}$ \\
\hline $\begin{array}{l}\text { Managerial Own- } \\
\text { ership }\left(\mathrm{X}_{2}\right)\end{array}$ & $\begin{array}{l}\text { The proportion of share ownership by man- } \\
\text { agement (Rahmadhani, 2015). }\end{array}$ & $\begin{array}{l}\mathrm{X}_{2}=\text { Total shares owned by management/ } \\
\text { Total shares outstanding } \times 100 \% \\
\text { (Rahmadhani, 2015) }\end{array}$ \\
\hline $\begin{array}{l}\text { Conflict of Inter- } \\
\text { est }\left(\mathrm{X}_{3}\right)\end{array}$ & $\begin{array}{l}\text { Description of the conflict between investors } \\
\text { and creditors (Paramita \& Cahyati, 2013). }\end{array}$ & $\begin{array}{l}X_{3}=(\text { Dividends paid / total assets }) \times 100 \% \\
(\text { Paramita \& Cahyati, 2013) }\end{array}$ \\
\hline $\begin{array}{l}\text { Leverage } \\
(Z)\end{array}$ & $\begin{array}{l}\text { The ratio of how much the company is fi- } \\
\text { nanced by debt (Sulastri et al., 2018). }\end{array}$ & $\begin{array}{l}Z=\text { Total debt / total equity } \\
\text { (Sulastri et al., 2018) }\end{array}$ \\
\hline
\end{tabular}

Source: Various references year 2019

data studied, for example, PT Adaro Energy, Tbk 2015 and PT Pelayaran Nelly Dwi Putri, Tbk 2016 which are companies in the very large interval class and the smallest interval class, both of which have different company sizes but have the equally high conservatism level namely 0.01914 and 0.03675 , respectively. This indicates that company size does not have a significant effect on the application of accounting conservatism.

Accounting conservatism has the goal of increasing company value. Thus, large and small companies will indirectly apply accounting conservatism to increase company value. In addition, inconsistency with the theory is possible because the go public companies have presented financial reports conservatively since they will be monitored by the government and re-examined by the financial services authority (Sinambela \& Almilia, 2018). Thus, the application of accounting conservatism is not influenced by company size because the application of regulation and supervision does not consider the size of the company. This research is in line with Geimechi \& Khodabakhshi(2015) as well as Sinambela \& Almilia (2018).

\section{The Effect of Managerial Ownership on Accounting Conservatism}

It is found that managerial ownership with accounting conservatism has a negative effect. This result is in line with the Bonus Plan Hypothesis which predicts that managers will use accounting methods that increase profits. The high level of managerial ownership drives the expropriation of the company in which aggressive accounting methods will tend to be used by management. This is because management is not only pursuing bonuses but also high dividends so that the presentation of financial reporting is less conservative.

The low managerial ownership drives management to be more careful in choosing accounting methods in order to maintain trust in interested parties. By applying accounting conservatism, the profits generated are considered not excessive, not misleading, and can be accounted for so that the funds that have been disbursed to the company are still entrusted to management to continue to be managed. This is in line with Xia \& Zhu (2009), Brilianti (2013), and Mohammed et al. (2017).

\section{The Effect of Conflict of Interest on Accounting Con- servatism}

In line with agency theory which reveals the relationship between investors and creditors who have a conflict of interest, the result of this study provides evidence that there is a positive influence on conflicts of interest with accounting conservatism. The conflict occurs because of excess dividend payments which investors use to take advantage of creditors' funds. This condition

Table 3. Hypothesis Test Results

\begin{tabular}{|c|c|c|c|c|c|}
\hline No & Hypothesis & $\boldsymbol{\beta}$ & Sig & $\alpha$ & Results \\
\hline 1. & $\mathrm{H}_{1}$ : Company size has a positive effect on accounting conservatism & 0.006 & 0.406 & 0.05 & Rejected \\
\hline 2. & $\begin{array}{l}\mathrm{H}_{2}: \text { Managerial ownership has a negative effect on accounting conserva- } \\
\text { tism }\end{array}$ & -0.030 & 0.029 & 0.05 & ted \\
\hline 3. & $\mathrm{H}_{3}:$ Conflict of interest has a positive effect on accounting conservatism & 0.032 & 0.022 & 0.05 & Accepted \\
\hline 4. & $\begin{array}{l}\mathrm{H}_{4}: \begin{array}{l}\text { Leverage moderates the effect of company size on accounting con- } \\
\text { servatism }\end{array}\end{array}$ & -0.008 & 0.538 & 0.05 & Rejected \\
\hline 5. & $\begin{array}{l}\mathrm{H}_{5}: \text { Leverage moderates the effect of managerial ownership on account- } \\
\text { ing conservatism }\end{array}$ & 0.031 & 0.036 & 0.05 & pted \\
\hline 6. & $\begin{array}{l}\mathrm{H}_{6}: \text { Leverage moderates the effect of conflict of interest on accounting } \\
\text { conservatism }\end{array}$ & -0.020 & 0.125 & 0.05 & Rejected \\
\hline
\end{tabular}

Source: Secondary data, Processed 2019 
causes creditors to worry about their funds so to reduce the conflicts that occur, management will apply more conservative financial reporting.

Investors and creditors are parties who play a role in the survival of the company. Especially creditors who have poured out a lot of funds for the company. This conflict of interest makes creditors worry about the safety of their funds so that they ask for conservative financial reporting. This pressure makes management more careful and presents conservative financial reporting. The result of this study is in line with Ahmed et al. (2002), Paramita \& Cahyati (2013) as well as Noodezh et al. (2015).

\section{The Effect of Company Size on Accounting Conserva- tism with Leverage as Moderator}

Leverage has not succeeded in moderating the relationship between company size and accounting conservatism. This result is not in line with the debt-equity hypothesis. This inconsistency is assumed because the companies do not feel threatened by high leverage since the companies might have anticipated risks by making good debt planning before owing to creditors. In addition, it is assumed that the creditors assess the corporate performance from other aspects such as profitability and profitability ratios so that high or low leverage does not make creditors monitor the company closely so that management does not feel pressured by them in making accounting decisions.

The results of the study, for example, PT Baramulti Suksessarana, Tbk 2017 is a company in a small interval class, has low leverage of 0.40194 but has accounting conservatism at the very high interval of 0.04779 . Then, PT Adl Sarana Armada, Tbk 2015 is a small company, has high leverage of 2.38539 but the level of accounting conservatism is very low of -0.09455 . The two companies illustrate that leverage is not successful in strengthening or weakening the relationship between company size and accounting conservatism.

\section{The Effect of Managerial Ownership on Accounting Conservatism with Leverage as Moderator}

In line with the debt-equity hypothesis, managerial ownership together with accounting conservatism is successfully moderated by leverage. The high leverage will increase the financial constraints the companies will face. The high leverage makes management tend to be more careful because it can be a threat to the company's survival since the companies will be more closely monitored by the creditors who feel threatened by their funds. Conversely, if the leverage is low, the financial constraints faced by the companies are smaller so that management is encouraged to use accounting methods that increase profits.

The existence of expropriation is driven because of the high level of managerial ownership so that it can reduce the application of conservative accounting. The relationship between managerial ownership and accounting conservatism will be moderated by the presence of leverage as moderating variable. High leverage will increase the financial risk to the company so that more conservative accounting is applied since the company will be more careful. On the other hand, low leverage means that the financial constraints faced by the company will be smaller, which causes creditors to be less strict in monitoring the company and drives management to provide more aggressive financial reports. The average leverage in this study is in the low interval class thus weakening the application of accounting conservatism.

\section{The Effect of Conflict of Interest on Accounting Con- servatism with Leverage as Moderator}

The relationship between conflicts of interest and accounting conservatism has not been successfully moderated by the presence of leverage. This result is not in line with the debt-equity hypothesis. This is possible because the creditors do not feel threatened by the security of their funds that have been disbursed to the companies. This is because it is assumed that efficient contracts have been made between the creditors and the companies so as not to create a conflict between interested parties in the companies. Thus, the creditors are not worried about their funds that can be misused for the benefit of investors only. Based on this trust, the creditors do not monitor the companies too closely and assess the corporate performance from other aspects outside of leverage such as profitability and rentability ratios.

The results of the study, for example, at PT Adi Sarana Armada, Tbk 2015 is a company that has high leverage of 2.38539 and has a very low conflict of interest 0.58702 but has a very low level of accounting conservatism of -0.09455 . Then, PT Perusahaan Gas Negara (Persero), Tbk 2016 has low leverage of 1.115575 and has a very low conflict of interest of 2.43856 . Meanwhile, the level of conservatism is high at 0.02874 . This proves that the conflict of interest on accounting conservatism has not been able to be moderated by leverage. This is because high leverage cannot strengthen the relationship between the two and vice versa, low leverage cannot weaken it.

\section{CONCLUSIONS}

The results of the study prove that managerial ownership and conflicts of interest can influence the application of accounting conservatism. Low managerial ownership will suppress the expropriation of the company thereby increasing the application of accounting conservatism. Conversely, the high managerial ownership will drive management to use more aggressive (liberal) accounting. Meanwhile, the high conflict of interest that occurs will drive management to apply accounting conservatism to reduce high conflicts. If the conflict of interest is low, the application of accounting conservatism will also be lower.

Accounting conservatism has the aim of increasing company value. Either big or small companies will indirectly apply accounting conservatism to increase company value. In addition, the government has supervised the go public companies, especially regarding taxes, so that both large and small companies tend to 
adopt accounting conservatism to reduce the political costs they have to pay. Thus, the application of accounting conservatism is not influenced by company size. Meanwhile, the relationship between managerial ownership and accounting conservatism is successfully moderated by the presence of leverage. This is because high or low leverage can affect the risk or financial constraints faced by the company, so that management decisions in choosing the accounting method, whether conservative or aggressive, will be affected. However, leverage is not able to moderate the relationship between company size and conflicts of interest with accounting conservatism.

The small sample becomes the limitation in this study because there are still many companies that do not meet the specified criteria. There is a lot of incomplete data, especially regarding dividends which are not necessarily paid and distributed by the companies every year. As well as the data related to managerial ownership that not every company has. Suggestions for further research are to expand the object of research by adding sectors so that the sample is larger. Furthermore, it is suggested to use other measurements to measure company size such as using stock market value and leverage using Debt to Asset Ratio and Long-Term Debt to Equity Ratio. This is done to compare the results between different measuring instruments and to prove the validity of the positive accounting theory used.

\section{REFERENCES}

Ahmed, A. S., Billings, B. K., Morton, R. M., \& Stanfordharris, M. (2002). The Role of Accounting. The Accounting Review, 77(4), 867-890. https://doi. org/10.1002/9781119199878.ch2

Brilianti, D. P. (2013). Faktor-Faktor yang Mempengaruhi Penerapan Konservatisme Akuntansi Perusahaan. Accounting Analysis Journal, 2(3), 268-275. https://doi. org/ISSN 2252-6765

Chariri, A., \& Ghozali, I. (2007). Teori Akuntansi (3rd ed.). Semarang: Badan Penerbit Universitas Diponegoro.

Geimechi, G., \& Khodabakhshi, N. (2015). Factors Affecting the Level of Accounting Conservatism in the Financial Statements of the Listed Companies in Tehran Stock Exchange. International Journal of Accounting Research, 2(4), 41-46.

Givoly, D., \& Hayn, C. (2000). The Changing time-series properties of Earnings, Cash Flows and Accruals: Has Financial Reporting Become More Conservative? Journal of Accounting and Economics, 29, 287-320.

Harrison Jr., W. T., Horngren, C. T., Thomas, C. W., \& Suwardy, T. (2012). Akuntansi Keuangan: International Financial Reporting Standards (Kedelapan; S. Saat, Ed.). Jakarta: Penerbit Erlangga.

Hery. (2017). Kajian Riset Akuntansi: Mengulas Berbagai Hasil Penelitian Terkini Dalam Bidang Akuntansi dan Keuangan (A. Pramono, Ed.). Jakarta: PT Grasindo.

Jensen, M., \& Meckling, W. (1976). Theory of the firm: Managerial behaviour, agency costs and ownership. Strategic Management Journal, 21(4), 1215-1224. Retrieved from http://search.ebscohost.com/login.aspx?direct= true $\& \mathrm{db}=$ buh $\& A N=12243301 \&$ site $=$ ehost-live

Juanda, A. (2007). Pengaruh Risiko Litigasi Dan Tipe Strategi Terhadap Hubungan Antara Konflik Kepentingan Dan Konservatisma Akuntansi. Simposium Nasional Akuntansi X.
Khosroshahi, M. A., Khanqah, V. T., \& Ghanavati, E. (2012). Studying the Effective Factors on Level of Accounting Conservatism in Financial Statements. Journal of Basic and Applied Scientific Research, 2(12), 1257412581. https://doi.org/ISSN 2090-4304

Lafond, R., \& Roychowdhury, S. (2008). Managerial ownership and accounting conservatism. Journal of Accounting Research, 46(1), 101-135. https://doi. org/10.1111/j.1475-679X.2008.00268.X

Moeinaddin, M., Branch, Y., Author, C., Dehnavi, H. D., Branch, B., Zareian, H., ... Branch, Y. (2012). The Relationship between Firm Size, Debt Contracts and the Nature of the Operations with the Accounting Conservatism. Interdisciplinary Journal Of Contemporary Research In Business, 4(6), 628-645.

Mohammed, N. F., Ahmed, K., \& Ji, X. D. (2017). Accounting conservatism, corporate governance and political connections. In Asian Review of Accounting (Vol. 25). https://doi.org/10.1108/ARA-04-2016-0041

Mousa Hamdan, A. M. (2011). The Impact of Company Size, Debt Contracts, and Type of Sector on the Level of Accounting Conservatism: An Empirical Study from Bahrain. International Journal of Business and Management, 6(7), 134-146. https://doi.org/10.5539/ ijbm.v6n7p134

Nabela, T. (2018). Pengaruh Pengungkapan CSR dan Tingkat Hutang terhadap Konservatisme Akuntansi dengan Risiko Litigasi sebagai Variabel Moderating. Skripsi. Semarang: Universitas Negeri Semarang.

Noodezh, H. R., Amiri, A., \& Moghimi, S. (2015). Investigation of the Relationship between Shareholders Conflict over Dividend Policy and Accounting Conservatism in Tehran Stock Exchange. International Journal of Academic Research in Accounting, Finance and Management Sciences, 5(3), 108-115. https://doi. org/10.6007/ijarafms/v5-i3/1803

Paramita, F., \& Cahyati, A. D. (2013). Pengaruh Konflik Kepentingan Terhadap Konservatisme Akuntansi dengan Risiko Litigasi dan Tipe Strategi Sebagai Variabel Pemoderasi. JRAK, 4(2), 42-63.

Pratiwi, Y. E. (2017). Pengaruh Kepemilikan Manajerial, Debt Covenant, Risiko Litigasidan Efektivitas Dewan Komisaristerhadap Konservatisme Akuntansi. Skripsi. Semarang: Universitas Negeri Semarang.

Rahmadhani, S. (2015). Analisa Faktor Faktor Yang Mempengaruhi Konservatisme Akuntansi. Jurnal Ilmu Manajemen Dan Akuntansi Terapan, 6 No. 1.

Sinambela, M. O. E., \& Almilia, L. S. (2018). Faktor-faktor yang mempengaruhi konservatisme akuntansi. Jurnal Ekonomi Dan Bisnis, 21(2), 289-312. https://doi. org/10.24914/jeb.v21i2.1788

Sulastri, A., Mulyati, S., \& Icih. (2018). Analisis Pengaruh Asean Corporate Governance Scorecard, Leverage, Size, Growth Opportunities, dan Earnings Pressure Terhadap Konservatisme Akuntansi (Studi Kasus pada Perusahaan Top Rank 50 ASEAN Corporate Governance Scorecard Di Indonesia yang terdaftar di Bursa Efek Indonesia pada Tahun 2013-2015). Accruals, 2(1), 41-67. https://doi.org/10.35310/accruals.v2i1.6

Sumiari, K. N., \& Wirama, D. G. (2016). Pengaruh Ukuran Perusahaan Terhadap Konservatisme Akuntansi Dengan Leverage Sebagai Variabel Pemoderasi. Jurnal Ekonomi Dan Bisnis, 4, 749-774.

Suwardjono. (2017). Teori Akuntansi: Perekayasaan Pelaporan Keuangan (Ketiga). Yogyakarta: BPFE-Yogyakarta.

Watts, R. (2003). Conservatism in accounting part I: Explanations and implications. Accounting Horizons. 
Retrieved from http://www.aaajournals.org/doi/ abs/10.2308/acch.2003.17.3.207

Watts, R. L., \& Zimmerman, J. L. (1990). Accounting Year Theory: Ten Perspective. The Accounting Review, 65(1), 131-156. https://doi.org/10.2307/247880

Wisuandari, I. K. P., \& Putra, I. N. W. A. (2018). Pengaruh Tingkat Kesulitan Keuangan dan Konflik Kepentingan pada Konservatisme Akuntansi dengan Risiko Litigasi Sebagai Pemoderasi. E-Jurnal Akuntansi Universitas Udayana, 23(2), 1521-1547.

Xia, D., \& Zhu, S. (2009). Corporate Governance and Accounting Conservatism in China. China Journal of Accounting Research, 2(2), 81-108. https://doi. org/10.1016/s1755-3091(13)60015-5 